\author{
V.N. Fomin ${ }^{1}$, E.R. Usmanova ${ }^{1}$, R.M. Zhumashev ${ }^{1}$, A.V. Pokussayev ${ }^{2}$, \\ G. Motuza ${ }^{3}$, Kh.B. Omarov', Yu.Yu. Kim ${ }^{1}$, M.Yu. Ishmuratova ${ }^{1}$ \\ ${ }^{I}$ Ye.A. Buketov Karaganda State University, Kazakhstan; \\ ${ }^{2} L L P$ «Tsentrgeolsemka», Karaganda, Kazakhstan; \\ ${ }^{3}$ Vilnius University, Lithuania \\ (E-mail:vitfomin@mail.ru)
}

\title{
Chemical-technological analysis of slags from the «Altynshoky» complex
}

\begin{abstract}
A historical monument on the top of the Altynshoky hill, first described by Academician K.I. Satpayev in 1935, consists of the so-called «Timur's Stone» and the mound, in the embankment of which there is a melted rock, and whose purpose has not been clarified yet. The proposed work for the first time presents the results of a multidisciplinary study of rock samples from the Altynshoky mound, the wreckage of a thermo-technical structure, and debris of rocks exposed to high temperatures. Using laser atomic emission and X-ray fluorescence analysis, geological study of samples and high-temperature processing in laboratory conditions, the identity of their chemical and mineralogical composition is presented. It is shown that the rock composing the hill and the rock from which the structure is built are identical and metamorphosed basalt. The fragments of the red rock and the slag from the center of the structure according to the ratio of the main components, namely, $\mathrm{Fe}, \mathrm{Si}, \mathrm{Al}$ and others are identical to the composing rock and were obtained from it without adding any ores or fluxes. The possibility of obtaining samples of red color and black vitreous slag from the main rock of the hill was confirmed experimentally. The geological study did not reveal the presence of metals in meltable concentrations. As a result of the research it was established that the construction was not used for metallurgical processes and apparently intended for other purposes, possibly ritual.
\end{abstract}

Keywords: laser inducted breakdown spectroscopy, X-ray fluorescence analysis, basalt, metabasalt, slag, historical thermotechnical structure, Timur's Stone, K.I. Satpayev, Altynshoky, Spireae hypericifolia.

\section{Introduction}

The Altynshoky hill (Karaganda oblast, Ulytau region, located north-west of the Ulytau Mountains, $47 \mathrm{~km}$ west of the Zhezkazgan-Arkalyk route, $12.5 \mathrm{~km}$ west of Sarlyk settlement) was first surveyed in 1935 by the Kazakhstan geologist, future academician of the USSR Academy of Sciences K.I. Satpayev during exploration surveys in the Central Kazakhstan. At the top of this hill an artificial stone mound with a truncated top and a depression in the center was found; among the stones there were numerous pieces of melted slag. At the base of the artificial embankment there was the so-called «Timur's Stone», which was a fragment of a rock with inscriptions in two languages: three lines in Arabic and eight lines in the Chagatai language made by Uighur writing [1]. In the scientific literature the inscription received a symbolic definition of the «Karsakpay inscription of Tamerlan» (Karsakpay settlement was inhabited in 1930-40s and it was the production point in the region near the Ulytau Mountains, where K.I. Satpayev worked). The stone was delivered in 1936 to the State Hermitage, to Leningrad (St. Petersburg), where it is still in the exposition on the medieval history of the Central Asia under the inventory code «cat. 195. Stone with the name of Timur. Golden Horde.1391» [2].

«Timur's Stone» is an evidence of the real events of 1391 - the campaign of Timur against the Golden Horde of Tokhtamysh, the part of the route that passed through the semi-desert regions of Betpak-Dala, past the Ulytau Mountain chain. «Book of Victories» - «Zafar-name» was written in the first quarter of the XV century. Sheref-ad-Din Ali Yazdi presented the testimony about one historical episode of this campaign: «... For a joyful survey of that steppe (the Ulytau district as the comment of the Authors) Timur ascended to the top of the mountain; the whole plain was all green. He stayed there that day, (then) a high order came out, so that the soldiers brought stones and a high sign, like a lighthouse was put in that place. Master stonecutters inscribed on it the date of that day, so that to leave the reminder on the face of time» [3].

The Altynshoky hill is about $50 \mathrm{~m}$ high. Outwardly it is not remarkable for anything and does not differ from other hills. But it is from its top that a wonderful view of the steppe panorama opens, with an expressive profile of the bluish Ulytau Mountains on the horizon. Apparently, it is no coincidence that Emir Timur chose precisely this peak for the construction of the installation of his memorable sign - a mound and a stone with an inscription. K.I. Satpayev, after examining the stone collapse of the embankment and the slag inside it, indicated that it was possible that the furnace for casting metal, lead was later installed in it. 
Further studies of the monument, as a rule, concerned the decoding or reconstruction of the route of the march of the Emir Timur against the Khan Tokhtamysh [4]. One of the latest surveys was done by LLP «Archaeological expertise» in 2010 [5]. Archaeologists noted that «visual inspection <...> showed that, first of all, we have the destroyed the structure of the furnace before us, where the rock was burnt». And they put the question of the need to analyze the slag in order to understand the purpose of this structure.

Interdisciplinary study of the memorial sign of the Emir Timur's «Altynshoky complex», using modern methods of chemistry, geology and botany is conducted in the domestic practice for the first time. The aim of the work is a chemical-technological analysis of the slag of the Altynshoky complex to understand its function. The obtained results can be used for the historical and cultural interpretation of this famous time monument of the Golden Horde.

\section{Topography and arrangement of the Altynshoky complex}

The investigated object is located on the top of the hill called Altynshoky, which enters the mountain chain, stretching along the NW-SE line. In the southwestern side, the mountain range abruptly breaks to the valley of the Jeti-Kyzriver and its tributaries. The river is the boundary between the Ulytau mountain system and the Turgai trough. The height of the mound above sea level is $453.5 \mathrm{~m}$, geographical coordinates are $\mathrm{N} 48^{\circ} 46,5125^{\prime} / \mathrm{E}^{\circ} 6^{\circ} 27,6445^{\prime}$ [5]. The object is considered in the form of a historical complex consisting at present of an artificial embankment and a stone with an inscription (a modern imitation-copy of the «Timur's Stone» made in the second half of the 1990s). The topographical diagram of the object is presented in Figure 1.

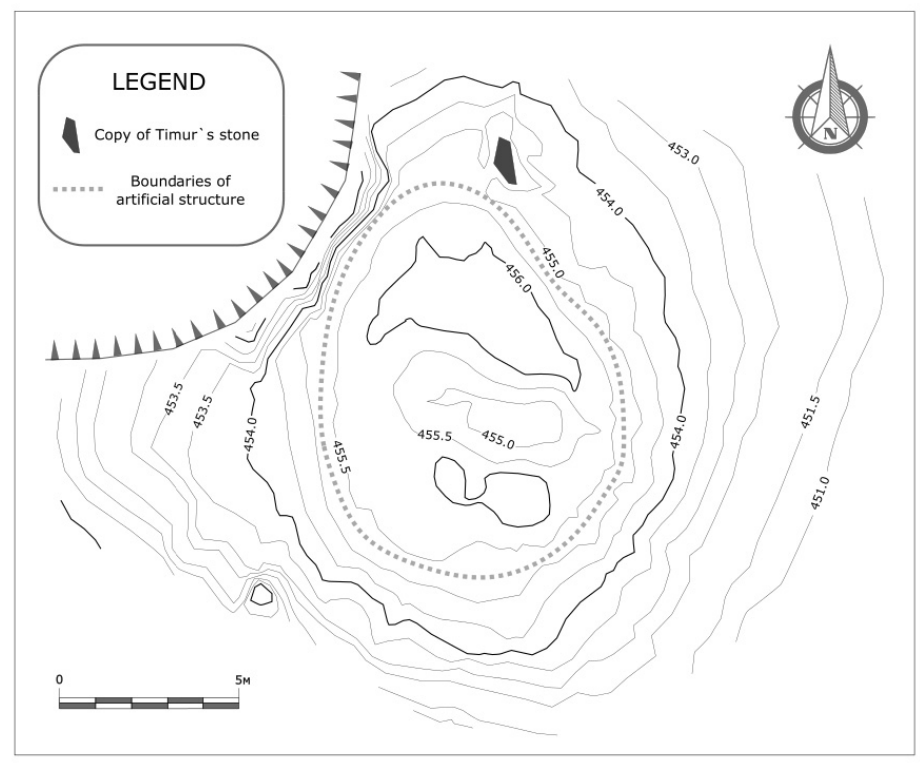

Figure 1. Topographical diagram of the «Altynshoky complex». Prepared by M.A. Antonov

The artificial mound consists of green schist - metamorphosed basalt with, dark green in color. The mound is oriented along the South-North line, with a slight deviation to the west. The external form of the mound is oval; the inner form is eight-shaped, with two local depressions. In the profile the embankment has the form of a truncated cone. The height of the stone embankment is $2.5 \mathrm{~m}$, the dimensions of the base are as follows: along the S-N line $-30.2 \mathrm{~m}$, along the $\mathrm{W}-\mathrm{E}$ line $-23.8 \mathrm{~m}$. The dimensions along the upper partare as follows: along the S-N line $-18.5 \mathrm{~m}$, along the W-E line $-12.0 \mathrm{~m}$. The depth of the inner space is $1.3 \mathrm{~m}$. The long axis is directed along the cliff edge [6]. The upper part of the embankment is made of thermally altered (calcinated) green schist. Inside the computation and in its internal depressions there are fragments of the calcinated green schist affected by temperature with large slag flows of $20 \times 40 \mathrm{~cm}-$ $30 \times 40 \mathrm{~cm}$. Small stones $(10 \times 15 \mathrm{~cm})$ with traces of melting and thermal alteration are also present on the outside of the mound, but in smaller quantity. Intensive roasting expressed by red-orange color indicates a strong effect of fire on the rock of the hill. Of course, the mound for a while was slightly destroyed under the influence of natural and anthropogenic factors. However, the complex, as a whole, has survived to our days in a satisfactory condition. 
At a visual survey of the mound, ten dilapidated artificial holes were previously found in it, which were located from the outside in the middle of the circle of the mound. Since the embankment of the structure is partially destroyed, scattered, most of the holes were in the collapse zone. The shape of the cross-section of the holes in the embankment is close to a rectangular, about $20-30 \mathrm{~cm} \times 30-40 \mathrm{~cm}$ in size. They are decorated horizontally with tiles placed under bulk stone; sometimes the fallen side tiles are fixed. Most likely, these holes belong to the air ducts, along which air was directed to the center of the structure, which was necessary to intensify the burning of fuel. The high temperature during the burning of the fire is evidenced by a large number of pieces of rock melted up to the slag inside the central part of the embankment. Unfortunately, it is not possible to reveal the outline and design of the air ducts. On the basis of these studies, it can be stated that there are artificially created holes located along the circumference of the middle of the mound, which, in all probability, belonged to the air ducts.

Thus, it is obvious that in the mound there is a well-thought-out system of air ducts, which was originally designed during its construction. It would be impossible to build a late furnace with canals into the mound without destroying the mound to the base and carrying the stone with the inscription. Therefore, there is no need to talk about a furnace of late origin in this building. The mound was conceived and built at the same time as a thermo-technical structure (a construction designed to work with fire is meant by it) and as a memorable sign of Timur. The channeling system for better draft of air was directed to the central deepening of the mound, where a powerful fire was ignited, which melted the rock to the state of slag. The structure was built on top, in a place where the wind was constantly blowing, contributing to the improvement of the natural draft necessary for an active influx of air to the fire.

\section{Petrographic description of the investigated samples}

Six samples of the unaltered rock composing the hill of Altynshoky were selected at its foot. According to a macroscopic definition, the samples are a schist of green color, consisting of chlorite, epidote, and plagioclase, fine-grained, presumably basalt metamorphosed under the conditions of the green schist facies of regional metamorphism. In the rock, veinlet of quartz 1-2 cm thick are observed with an epidote rims and with fine dissemination of magnetite.

Two samples of rock taken from the top of the hill (the place of the fireplace) are the same green schists, subject to varying degrees of high temperature effect from calcinations up to melting. One sample is very fine-grained schists of the reddish-brown color acquired during firing. Another sample is a slag of black color, a glassy texture, a bubbly structure, that appears to have been formed as a result of the melting of the rock at high temperature. The remains of charred vegetation are preserved in the slag.

Slag, as it is known, is a product or waste of smelting, which can be formed not only during metallurgical processes. In this case, the chemical analysis of the slag-like rock makes it possible to establish the possibility of using the structure for metallurgical purposes and to determine the origin of the slag from the rock composing the Altynshoky hillock or from other sources.

\section{Modeling of metabasaltcalcination conditions}

In order to test the possibility of modifying the rock composing the Altynshoky hill, under the influence of high temperature, the samples were heated in a muffle furnace in an air atmosphere. When heated to $1000{ }^{\circ} \mathrm{C}$ for 2 hours, the natural color of the surface of the sample (dark green) was replaced by a dark red, similar to the color of the surface of the stones at the top of the hill, which fell into the fire zone (Fig. 2). When calcining to $1000^{\circ} \mathrm{C}$, samples cracked, and some of them formed a glassy flow.

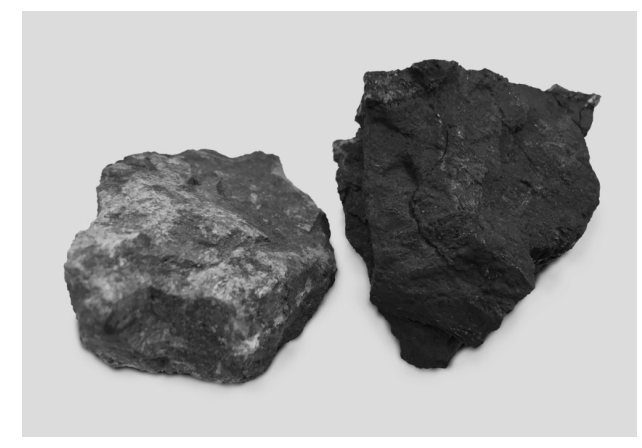

Figure 2. Samples of native (left) and calcined at $1000{ }^{\circ} \mathrm{C}$ 
When the temperature is raised to $1100{ }^{\circ} \mathrm{C}$, the samples begin to melt. In order to simulate the historical conditions, 2-3 pieces of birch coal were added to the sample of roughly crushed rock $(5-8 \mathrm{~mm})$ in an Alundum crucible and heated at $1100-1150{ }^{\circ} \mathrm{C}$ for $4-5$ hours. At the same time, the rock melted and the formation of black slag visually similar to the historical sample occurred (Fig. 3).

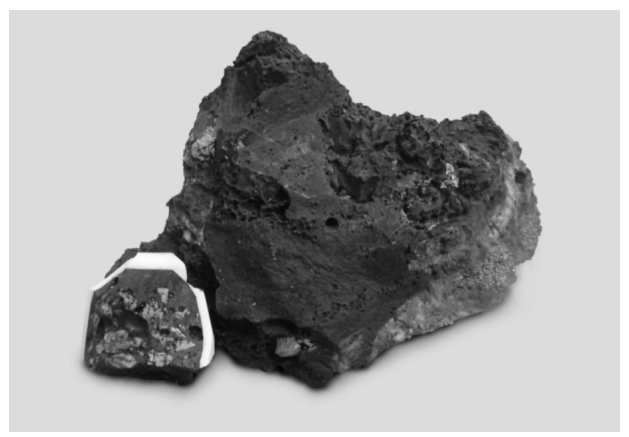

Figure 3. Slag in a crucible and a historical sample

The visual similarity of the samples suggested that the historical samples were obtained under similar conditions and had the same chemical composition. A comparative qualitative analysis of the samples was carried out using the LIBS Matrix Continuum Laser-Induced Breakdown Spectroscopy. The quantitative determination of the main elements and the geological identification of the minerals were carried out using the NittonX X-ray fluorescence analyzer.

\section{Spectrometric study of samples}

Recently, archeological studies have begun to use atomic emission spectroscopy with the laser excitation of the spectrum [7]. For archaeologists, minimal damage to the sample during analysis, the possibility of point measurements and other advantages of the method are important [8]. The considerable heterogeneity of the samples makes it impossible for them to be quantitatively analyzed by the LIBS method without the complete destruction. Qualitative and comparative semi-quantitative analysis of samples of primary metabasalt, historical calcined metabasalt and slag, calcined metabasalt and slag obtained in the laboratory were carried out using a LIBS spectrometer.

In the spectra of all samples, intense lines of silicon, aluminum, titanium, iron, magnesium, and calcium, as well as other elements presented in small amounts, were detected. Fragments of the atomic-emission spectra of the samples are shown in Figure 4 (a-d).

As it can be seen from the fragments of the spectra, the intensities of the lines of the major elements (silicon, iron, magnesium and aluminum) are fairly close, taking into account the relatively high error in the analysis of heterogeneous objects. The intensity of the titanium lines in the historically burned (but not refined) sample is reduced, which is probably due to chemical leaching for nearly 700 years after baking.

Statistical evaluation of the reliability of the conclusions made on the basis of LIBS data was carried out using the coefficient of variation (1).

$$
C_{V}=\frac{\sigma}{\bar{x}}(1), \text { where } \sigma=\sqrt{\sum \frac{(x-\bar{x})^{2}}{n}} .
$$

The basis for the statistical evaluation was the following known regularities [8]: 1) random factors affect the intensities of an individual spectral line more than the intensity ratio of the two lines; 2) concentration of any element in a single sample is a constant value, so the scatter of intensities of different spectral lines of one element depends only on random factors. Therefore, comparing the coefficients of variation for the ratio of the intensities of the lines of one element and the ratio of the intensity of the lines of different elements, one can judge as the identity of the spectra of the samples.

Table shows the measured values of the radiation intensities at different wave lengths, their ratios in different combinations, and the values of the coefficients of variation determined for them. As it can be seen from the data in the table, for aluminum lines, the coefficients of variation of the ratio of line intensities lie in the range of 3.9-23.7\%, silicon - 4.9-11.6\%, iron - 16.6-23.1\%. The coefficients of variation for the ratios of the intensities of the lines of different elements are: $\mathrm{Al} / \mathrm{Si}-3.6-24.9 \%$; $\mathrm{Al} / \mathrm{Fe}-14.6-21.6 ; \mathrm{Si} / \mathrm{Fe}$ is $8.7-22.2 \%$. 


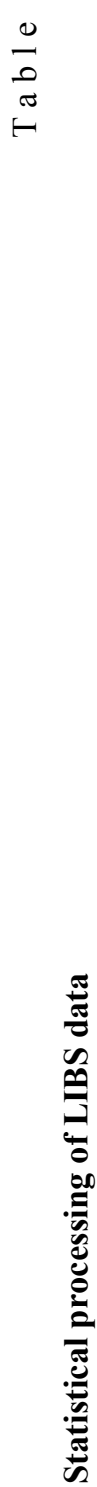

\begin{tabular}{|c|c|c|c|c|c|c|c|c|c|c|c|c|c|c|c|}
\hline 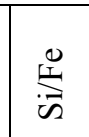 & $\mid \begin{array}{l}0 \\
\vdots \\
n \\
0\end{array}$ & & & $c$ & $\stackrel{H}{u}$ & 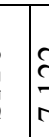 & & & & $\frac{8}{0}$ & $\stackrel{0}{\stackrel{D}{ \pm}}$ & & & & \\
\hline 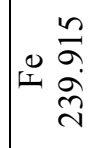 & $\overrightarrow{\vec{\nabla}}$ & & $\begin{array}{l}? \\
0 \\
0\end{array}$ & & & 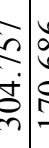 & & & & $\frac{\pi}{0}$ & 일 & $\begin{array}{l}1 \\
0 \\
0 \\
0 \\
0 \\
-\end{array}$ & & & \\
\hline $\bar{n} \underset{\sim}{\stackrel{m}{\sigma}}$ & 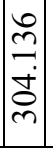 & & 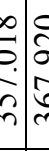 & 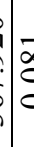 & & $\begin{array}{lll}0 & \\
0 \\
0 \\
0 \\
0 \\
0\end{array}$ & 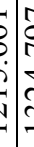 & $m$ & $\begin{array}{l}\propto \\
\propto \\
\infty \\
\infty \\
\sim \\
i\end{array}$ & $\frac{8}{0}$ & 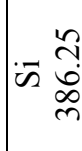 & $\frac{\hat{m}}{\hat{m}}$ & 8 & & \\
\hline$\stackrel{0}{\ll}$ & $\mid \begin{array}{l}\overrightarrow{0} \\
0 \\
0 \\
\end{array}$ & & & 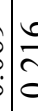 & & $\bar{\tau}$ & & & $\delta$ & $\stackrel{?}{\stackrel{?}{\circ}}$ & 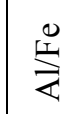 & $\mid \begin{array}{l}\hat{8} \\
\dot{m}\end{array}$ & 3 & & $\begin{array}{c}\infty \\
\infty \\
c \\
c \\
c \\
c \\
c\end{array}$ \\
\hline $\begin{array}{ll} & \frac{n}{2} \\
0 & \alpha \\
& \frac{\partial}{2}\end{array}$ & $\mid \begin{array}{l}n \\
\vec{f} \\
\overrightarrow{8} \\
\end{array}$ & & $\begin{array}{l}c \\
? \\
t \\
c\end{array}$ & & i & 胥 & & & & $\stackrel{g}{g}$ & 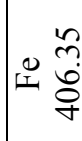 & $\begin{array}{l}\text { तु } \\
0 \\
0 \\
0 \\
0\end{array}$ & & 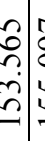 & 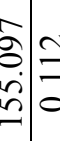 \\
\hline « & $\mid \begin{array}{l}\overrightarrow{\widehat{\sigma}} \\
\stackrel{0}{0}\end{array}$ & 8 & & & & & & & & & 《 $\frac{n}{\stackrel{0}{\circ}}$ & 18 & & 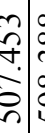 & 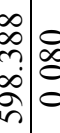 \\
\hline
\end{tabular}

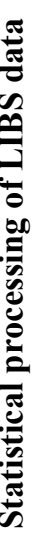

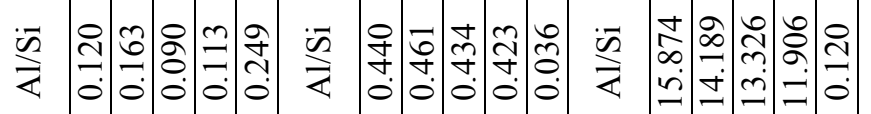

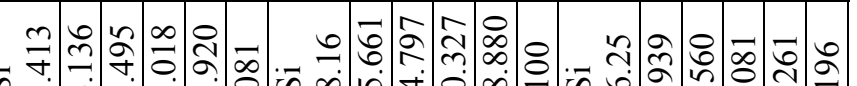

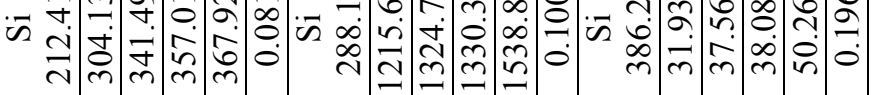

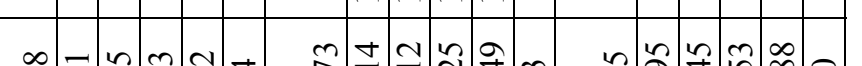

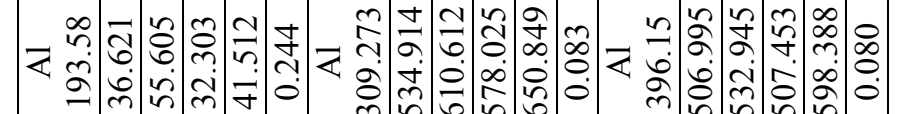

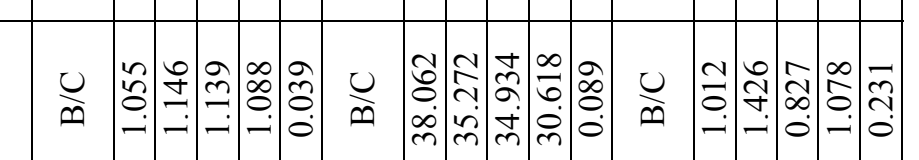

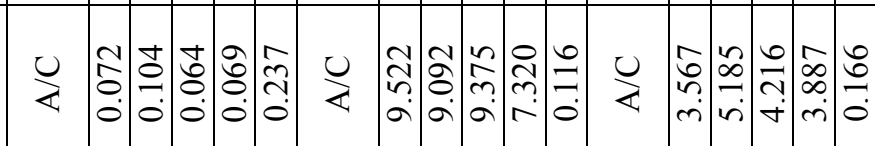

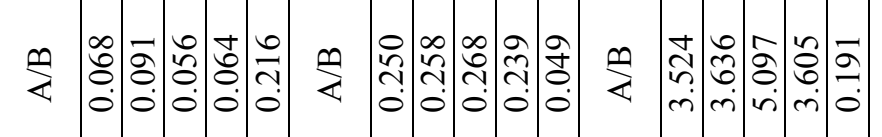

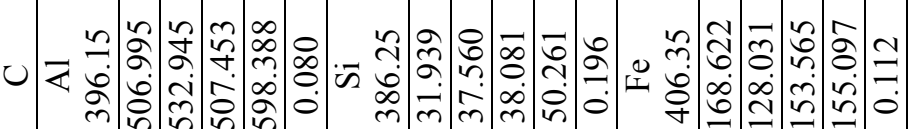

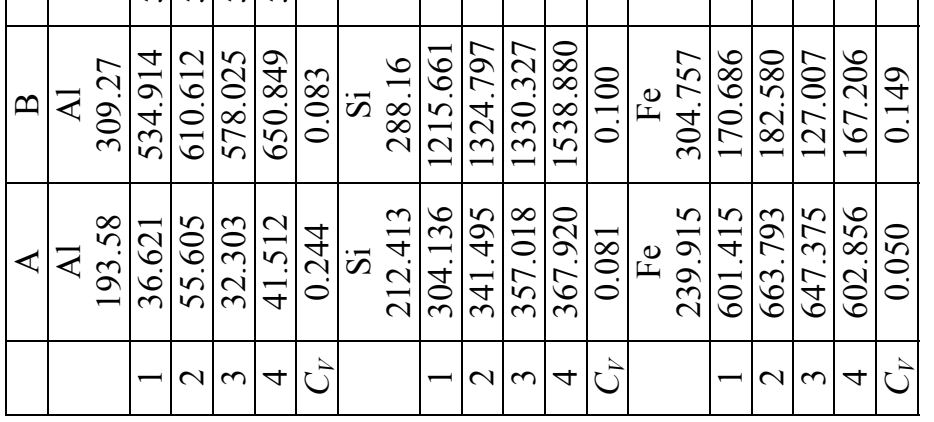
$\stackrel{1}{\Xi}$ 4 胥 $\stackrel{0}{ \pm}$ 幽 릉 $\stackrel{\square}{ \pm}$ त 可 음 옹 를 $\stackrel{\Xi}{\Xi} . \Xi$ $\Xi \bar{D}$ oî 录送 80 \& $\Xi m$ 흥 $\frac{0}{8}$ क 응 氙

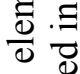
I 40 论 卷 $\stackrel{\infty}{=}$

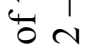
: $\frac{0}{\tilde{E}}$ . . 흘 రृ อิ ¿ ต : ¿ บ. ๑ ¿ 党 

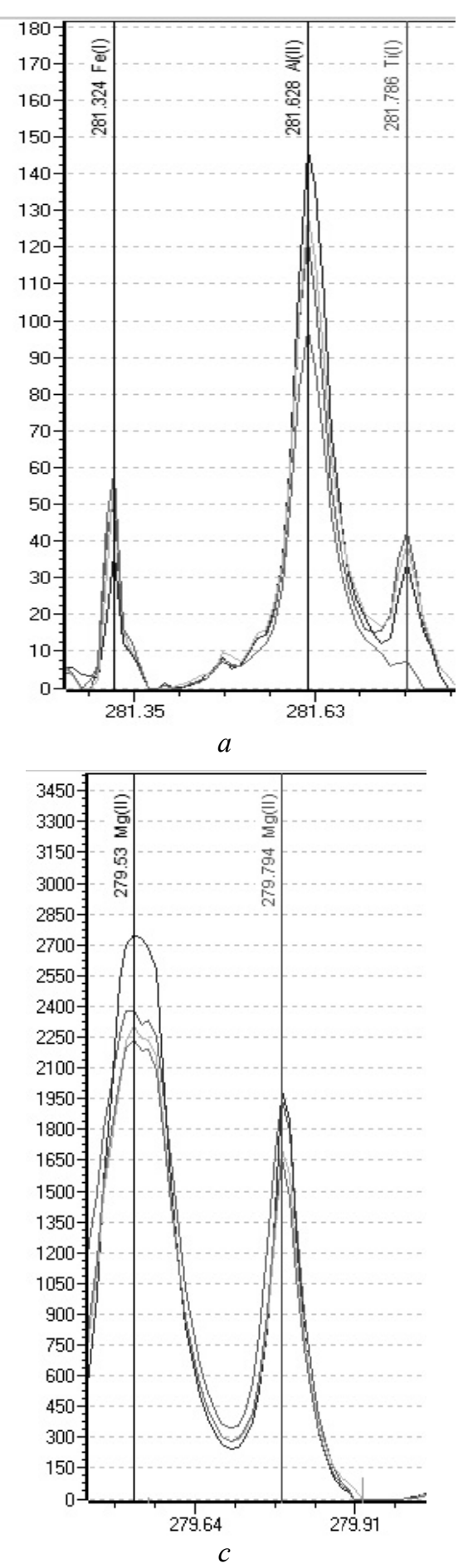
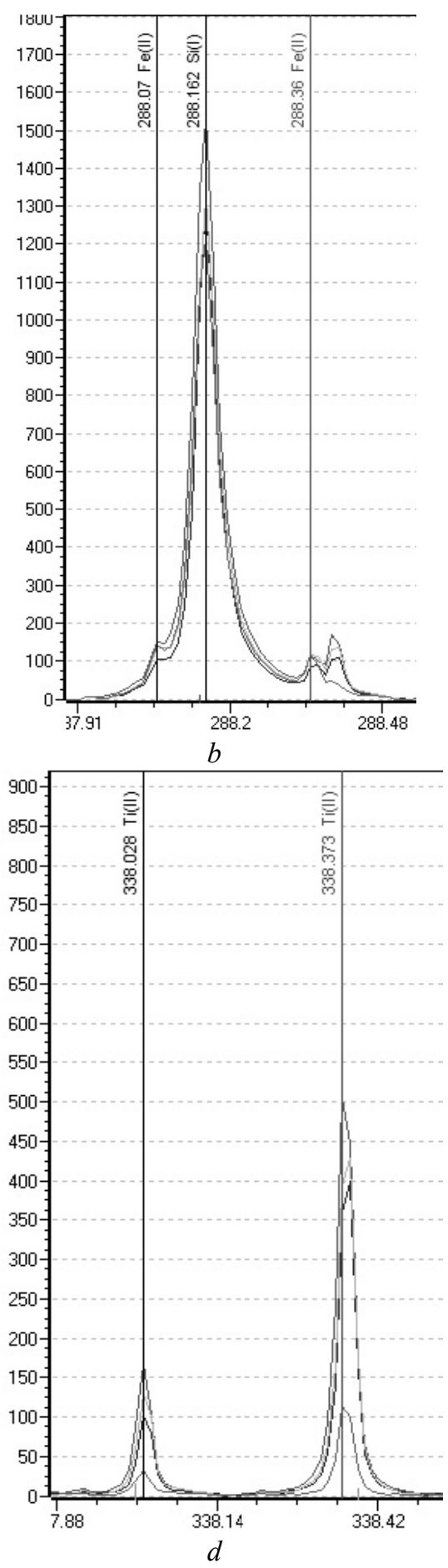

Lines of $a$ - iron, aluminum, titanium; $b$ - iron and silicon; $c$ - magnesium; $d$ - titanium.

The $\mathrm{Y}$ axis is the relative intensity. The $\mathrm{X}$ axis is the wave length, $\mathrm{nm}$

Figure 4. Fragments of atomic emission spectra of samples

Since the coefficients of variation for the ratio of the intensities of the lines of one element are close to the variation coefficients for the ratio of the intensities of the lines of different elements, we can state that the ratio of the concentrations of iron, aluminum and silicon in all samples is very close, and the origin is the same.

A comparison of the data of the quantitative X-ray fluorescent analysis of a sample of slag and the average chemical composition of basalt [9] using X-ray fluorescence analysis is shown in Figure 5. The graphs are similar in shape, which indicates that the rock composition, represented by slag, is close to the chemical. 


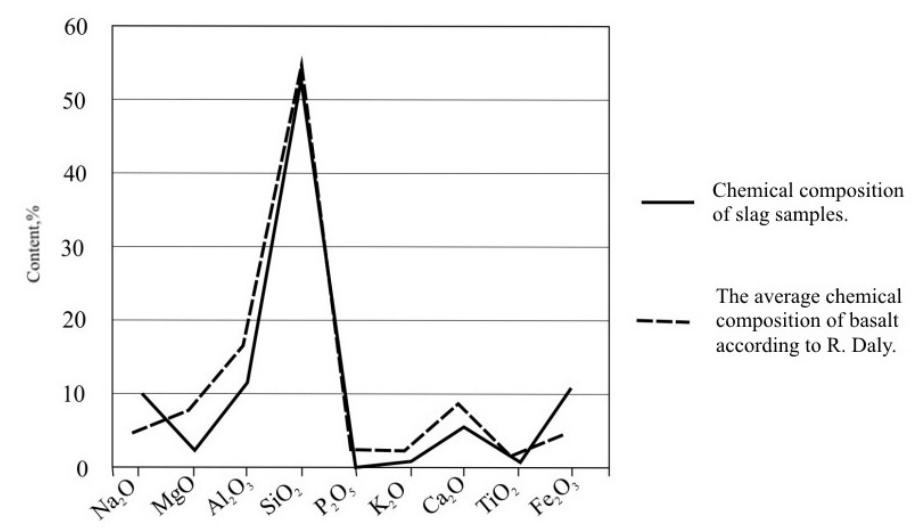

Y-axis — \% of content; _ chemical composition of slag samples;
- - - average chemical composition of basalt according to [9]

Figure 5.Comparison of the results of chemical analysis of slag samples and the average chemical composition of basalts

The chemical composition of three samples of rock subjected to different degrees of temperature influence, one sample of laboratory slag and six samples of rock from the middle of the foot of the hill was studied. To compare the results of the chemical composition of rock samples, graphs of geochemical spectra of concentrations of chemical elements characterizing these samples were constructed (Fig. 6). Clark concentration is the ratio of the element's content in the rock to the clark element in the earth's crust.

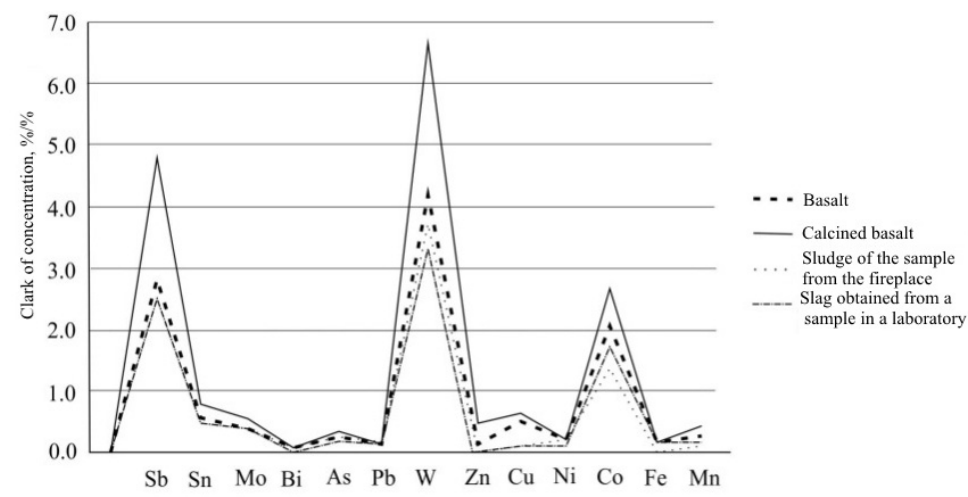

Figure 6. Geochemical spectra of clarks of chemical concentrations elements in the rock samples from the mound of the Altynshoky hill. From top to bottom: metabasalt, calcined metabasalt, slag sample from the mound, slag received from basalt sample in the laboratory

When comparing the graphs, the identity of the qualitative chemical composition of all samples and the closeness of their quantitative composition is observed; all the graphs are parallel. The concentration clusters of such metals as $\mathrm{Au}, \mathrm{Ag}, \mathrm{Pb}, \mathrm{Cu}, \mathrm{Sn}, \mathrm{Zn}, \mathrm{Fe}, \mathrm{Mn}$ do not exceed 1, which indicates a low concentration of these elements in the samples of the original rock and effects of temperature exposure. Obviously, the original rock cannot be an ore for smelting iron, silver, copper, gold or lead.

Comparing the samples obtained by heat treatment of the native rock from the Altynshoky hill, as well as the data of the Leningrad Nuclear Power Plant and the X-ray fluorescence analysis of the samples of the historical calcined and fused rock, it should be noted that there is a coincidence of their chemical composition, i.e. burned and melted samples are obtained from the original rock of the hills, without the introduction of other mineral components. To obtain any of the metals that make up the rock of the Altynshoky volcano in a free state in the conditions of a fireplace is not possible because of their relatively low concentrations. Thus, the formation of slag occurred not as a result of metallurgical processes. 


\section{Characteristic of probable fuel}

In this area of Ulytau as a fuel, a shrubby plant of the Rosaceae family could be used - Spiraea hypericifolia L. (the Kazakh name is shaykuraitobylgy). This shrub up to $150 \mathrm{~cm}$ high, with brown rodshaped branches with umbrellas of flowers, grows in mass on ravine and stony slopes in the steppe, foreststeppe zones, in bushes and on the banks of mountain rivers. Branches and wood of the Spiraea hypericifolia along with other substances contain essential oils and resins. Spiraea hypericifolia burns well and quickly and with its smoke, the Kazakh fumigate sabu - a leather or wooden container for making kumys. They use smoldering stalks of sturgeon to smoke horsemeat, lamb. In the area of the Altyshoky hill, the Spiraea hypericifolia grows at the foot, in the hollows, on the stony slopes of the hills. Here it is a mass artisanal formation [10]. Its burnt branches were preserved in the pores of the slag, and it was used as a combustible material for the fireplace. Spiraea hypericifolia burns quickly, giving a strong heat. Basalt rock, as the experiment has shown, melts to a slag state at a temperature of $1000-1100^{\circ} \mathrm{C}$. Consequently, the fire demanded more fuel, capable of giving a fire of heat. According to [11], the burning temperature of some types of wood can exceed $1000^{\circ} \mathrm{C}$. An even higher temperature, up to $1300^{\circ} \mathrm{C}$, can be achieved by burning charcoal with air purging [12]. With the simultaneous loading of a large number of branches into the fire, there is a temporary lack of oxygen and the formation of charcoal, which subsequently leads to high-temperature combustion. Apparently, the burning of the fire, lit by the soldiers of Timur, in this regime led to the melting of metabasalt.

\section{Conclusion}

Based on the carried out studies using the methods of natural sciences, the following reconstruction of the Altynshoky complex is proposed:

- the structure at the top of the hill is a thermo-technical structure in the form of a mound with a notch in the center and a system of traction air ducts arranged and passing inside the mound;

- the structure was not intended for metallurgical smelting, it probably was built with the purpose of building a powerful fireplace in it, the fire in which burned for 2-3 days;

- as a result of the high temperature of the fire burning in the excavation of the embankment, the rock was melted prior to slag formation on its surface;

- the fire of the bonfire affected the rocks in the central part of the mound and the openings of the air ducts, leaving spots of fires;

- the flame of the fire burning in the central depression of the mound did not affect the stone with the inscription, which was apparently installed prudently at the base of the mound.

So, as a result of spectral analysis and geological study of slags and rock rocks, we came to the following conclusions:

- the historical complex of Altynshoky consists of a thermo-technical structure that has been preserved in the form of a mound and a stone with an inscription;

- this heat engineering structure is not classified as a metallurgical furnace and it was intended for the construction of a fire with a high combustion temperature, which resulted in firing and melting of metabasalt rock;

- Altynshoky complex as a memorable sign of the Emir Timur combines utilitarian and sacral functions and appears as a ritual object, whose historical and cultural interpretation is waiting for its solution.

\section{Acknowledgments}

We thank B.S. Kozhakhmetov (director of the National Historical, Cultural and Natural Reserve Museum «Ulytau»); A.S. Omar (Akim of the Ulytau district); M.V. Bedelbayeva (Director of the Museum of Archeology and Ethnography of Academician Ye.A. Buketov Karaganda State University); P.V. Blinov (chief surveyor of the KBRU of JSC «Aluminum of Kazakhstan»).

The work was supported by a grant from the Ministry of Education and Science of the Republic of Kazakhstan "Research and Documentary of Cultural Landscapes in Central Kazakhstan Based on Modern Technologies and Interdisciplinary Methods». When interpreting the spectral data, the methods developed within the framework of the MES RK grant «Development of a method for obtaining and processing atomic emission spectra, using experimental design techniques» were applied. 
1 Григорьев А.П. Надпись Тимура 1391 г. / А.П. Григорьев, Н.Н. Телицын, О.Б. Фролова // Историография и источниковедение истории стран Азии и Африки. - Вып. ХХІ. - СПб.: Изд-во СПб. ун-та, 2004. - С. 3-24.

2 Крамаровский М.Г. «Камень Тимура» как феномен чингизидской истории и культуры / М.Г. Крамаровский // Золотая Орда. История и культура: монография. - СПб.: Славия, 2005. - С. 167-170.

3 Тизенгаузен В.Г. Сборник материалов, относящихся к истории Золотой Орды: монография: Т. 2 / В.Г. Тизенгаузен. — М.; Л.: Изд-во АН СССР, 1941. - С. 161.

4 Костюков В.П. Несколько замечаний к походу Тимура 1391 г. / В.П. Костюков // Золотоордынская цивилизация: Сб. ст. - Вып. 3. - Казань: Изд-во «Фэн» АнРТ, 2010. - С. 172-183.

5 Воякин Д.А. Исследования на комплексе «Алтыншокы» (Надпись Тимура). Информационная страница из отчёта «Научный отчёт AR-12/54, Улытау 2010» / Д.А. Воякин // Предоставлено автором.

6 Горная энциклопедия [Электронный ресурс]. — Режим доступа: http://www.mining-enc.ru/b/bazalt/.

7 Anglos D. Laser-Induced Breakdown Spectroscopy in Art and Archaeology / D. Anglos // Applied spectroscopy. — 2001. Vol. 55. - No. 6. - P. 186-205.

8 Кремерс Д. Лазерно-искровая эмиссионная спектроскопия: книга / Д. Кремерс, Л.М. Радзиемски. — М.: Техносфера, 2009. - $360 \mathrm{c}$.

9 Daly R.A. Average chemical compositions of igneous rock types / R.A. Daly // Am. Acad. Arts and Sci. Proc. — 1910. Vol. 45. - P. 211-240.

10 Ишмуратова М.Ю. Флора гор Улытау (Центральный Казахстан) / М.Ю. Ишмуратова, Г.Ж. Мырзалы, В.И. Ивлев, А.Н. Матвеев. - Караганда: РИО «Болашак-Баспа», 2016. - С. 37.

11 Температура горения дров различных пород дерева [Электронный ресурс]. - Режим доступа: http://cotlix.com/temperatura-goreniya-drov

12 Температура горения угля: виды углей и их свойства [Электронный ресурс]. — Режим доступа: http://teplo.guru/pechi/temperatura-goreniya-uglya.html

\author{
В.Н. Фомин, Э.Р. Усманова, Р.М. Жумашев, А.В. Покусаев, \\ Г. Мотуза, Х.Б. Омаров, Ю.Ю. Ким, М.Ю. Ишмуратова
}

\title{
«Алтыншоқы» кешенінен алынған қождың химиялық-технологиялық талдауы
}

1935 ж. алғаш рет академик Қ.И. Сәтпаев сипаттаған Алтыншоқы шыңындағы тарихи ескерткіш «Темірдің тасынан» және құрамында белгісіз мақсатта ерітілген тау жынысы бар қорғаннан тұрады. Ұсынылып отырған мақалада алғаш рет Алтыншоқы шыңынан алынған тау жыныстарының, жылутехникалық құрылыстың қалдықтарының, жоғары температура әсеріне ұшыраған тау жыныстары сынықтарының пәнаралық зерттелу нәтижелері келтірілді. Лазерлік атомды-эмиссиондық және рентгенфлуоресценттік талдау көмегімен, үлгілерді геологиялық зерттеу және лабораториялық жағдайда жоғары температуралық өңдеу арқылы олардың химиялық және минералогиялық құрамының бірегейлігі ұсынылды. Шоқыны және құрылысты құрайтын тау жыныстары бірегей екендігі көрсетіліп, оның базальт екені анықталды. Қызыл түсті тау жынысы және құрылыстың ортасынан алынған қож $\mathrm{Fe}, \mathrm{Si}, \mathrm{Al}$ және тағы басқа негізгі компоненттерінің ара қатынасы бойынша шоқыны құрайтын жыныспен бірегей және одан қандай да бір кен немесе флюс қоспасыз алынған. Қызыл түсті үлгілерді және қара түсті шыны тәріздес қожды шоқының негізгі тау жынысынан алу тәжірибе барысында дәлелденді. Геологиялық зерттеулер балқытуға қажет көлемдегі металдың жоқтығын анықтады. Зерттеу нәтижесінде құрылыстың металлургиялық үдеріс үшін пайдаланылмағаны белгілі болды, шамасы, ол басқа, мүмкін, рәсімдік мақсатта қолданылған.

Кілт сөздер: лазерлік атомды-эмиссиондық спектралды талдау, рентгенофлуоресценттік талдау, базальт, метабазальт, қож, тарихи жылутехникалық құрылыс, Темірдің тасы, Қ.И. Сәтпаев, Алтыншоқы, шайқурай тобылғы.

\section{В.Н. Фомин, Э.Р. Усманова, Р.М. Жумашев, А.В. Покусаев, Г. Мотуза, Х.Б. Омаров, Ю.Ю. Ким, М.Ю. Ишмуратова}

\section{Химико-технологический анализ шлаков из комплекса «Алтыншокы»}

Исторический памятник на вершине сопки Алтыншокы, впервые описанный академиком К.И. Сатпаевым в 1935 г., состоит из так называемого «камня Тимура» и кургана, в составе насыпи которого есть оплавленная порода, и его назначение до сих пор не выяснено. В предлагаемой статье впервые приведены результаты мультидисциплинарного исследования образцов породы с сопки Алтыншокы, обломков, слагающих теплотехническое сооружение, и обломков породы, подвергшихся 
действию высокой температуры. С помощью лазерного атомно-эмиссионного и рентгенофлуоресцентного анализа, геологического изучения образцов и высокотемпературной их обработки в лабораторных условиях показана идентичность их химического и минералогического состава. Показано, что зеленоватая порода, слагающая сопку, и порода, из которой сложено сооружение, идентичны и представляют собой базальт. Фрагменты породы красного цвета и шлак из центра сооружения по соотношению основных компонентов - Fe, $\mathrm{Si}, \mathrm{Al}$ и др. - идентичны слагающей сопку породе и получены из неё, без добавления каких-либо руд или флюсов. Возможность получения образцов красного цвета и чёрного стекловидного шлака из основной породы сопки подтверждена экспериментально. Геологическое исследование не выявило присутствия металлов в пригодных для выплавки концентрациях. В результате исследования установлено, что сооружение не использовалось для проведения металлургических процессов и, видимо, предназначалось для других целей, возможно, ритуальных.

Ключевые слова: лазерный атомно-эмиссионный спектральный анализ, рентгенофлуоресцентный анализ, базальт, метабазальт, шлак, историческое теплотехническое сооружение, камень Тимура, К.И. Сатпаев, Алтыншокы, таволга зверобоелистная.

\section{References}

1 Grigoriev, A.P., Telitsyn, N.N., \& Frolova, O.B. (2004). Nadpis Timura 1931 h. [Timur inscription of 1391]. Istoriohraphiia $i$ istochnikovedenie istorii stran Azii $i$ Afriki - Historiography and source study of the history of the countries of Asia and Africa. Issue XXI. Saint Petersburg: Publ. house of Saint Petersburg University [in Russian].

2 Kramarovskiy, M.G. (2005). «Kamen Timura» kak fenomen chinhizidskoi istorii i kultury [«The Stone of Timur» as a phenomenon of Chingisid history and culture]. Zolotaia Orda. Istoriia i kultura - The Golden Horde. History and culture. Saint Petersburg: Slaviia [in Russian].

3 Tizengauzen, V. G. (1941). Sbornik marerialov, otnosiashchikhsia k istorii Zolotoi Ordy [Collection of materials related to the history of the Golden Horde. (Vol. 2). Moscow; Leningrad: Publishing house of the Academy of Sciences of the USSR [in Russian].

4 Kostyukov, V.P. (2010). Neskolko zamechanii k pokhodu Timura $1391 \mathrm{~h}$. [A few remarks to Timur's campaign of 1391]. Zolotoordynskaia tsivilizatsiia — Golden Horde civilization. Iss. 3, Kazan: Publ. house «Fen» AnRT [in Russian].

5 Voyakin, D.A. (2010). Issledovaniia na komplekse «Altynshoky» (Nadpis Timura) [Research on the «Altynshoky» complex (Timur's inscription)]. Information page from the report «Scientific Report AR-12/54, Ulytau 2010». Provided by the author [in Russian].

6 Hornaia entsiklopediia [Mountain encyclopedia]. mining-enc.ru/b/bazalt/. Retrieved from http://www.mining-enc.ru/b/bazalt/ [in Russian].

7 Anglos, D. (2001). Laser-Induced Breakdown Spectroscopy in Art and Archaeology. Applied spectroscopy, 55(6), $186-205$.

8 Kremers, D., \& Radziemski, L. (2009). Lazerno-iskrovaia emissionnaia spektroskopiia [Laser-Induced Breakdown Spectroscopy]. Moscow: Tekhnosphera [in Russian].

9 Daly, R.A. (1910). Average chemical compositions of igneous rock types. Am. Acad. Arts and Sci. Proc., 45, $211-240$.

10 Ishmuratova, M. Yu., Myrzaly G. Zh., Ivlev V.I., \& Matveyev A.N. (2016). Flora hor Ulytau (Tsentralnyi Kazakhstan) [Flora of the Ulytau Mountains (Central Kazakhstan)]. Karaganda: Bolashak-Baspa [in Russian].

11 Temperatura horeniia drov razlichnykh porod dereva [Burning temperature of firewood of different types of wood]. cotlix.com/temperatura-goreniya-drov. Retrieved from http://cotlix.com/temperatura-goreniya-drov [in Russian].

12 Temperatura horeniia uhlia: vidy i ikh svoistva [Combustion temperature of coal: types of coals and their properties]. teplo.guru/pechi/temperatura-goreniya-uglya. Retrieved from http://teplo.guru/pechi/temperatura-goreniya-uglya.html [in Russian]. 